\title{
REPENSANDO 0 PRESIDENCIALISMO: CONTESTAÇÕES E QUEDAS DE PRESIDENTES NA AMÉRICA DO SUL*
}

\author{
Kathryn Hochstetler**
}

Desde que os países sul-americanos retornaram ao governo civil nos anos 1970 e 1980, 23\% de seus presidentes eleitos têm sido forçados a deixar o cargo antes do final de seus mandatos. Esse espantoso índice de quedas presidenciais prematuras tem recebido pouca atenção sistemática, embora devesse ser um elemento crítico nos debates acerca da qualidade da democracia e da possível instabilidade nos sistemas presidenciais. Este artigo enfoca os desafios: como e por que os sul-americanos exigem que os presidentes deixem o cargo antes do fim do mandato? Desde 1978, os desa-

\footnotetext{
* Publicado como "Rethinking presidentialism: challenges and presidential falls in South America". Comparative Politics, jul. 2006, pp. 401-418. Esta tradução em português é publicada com a permissão dos detentores dos direitos autorais, a quem agradecemos. Tradução de Valerie Rumjanek Chaves, a quem também agradecemos.

** Gostaria de agradecer a Javier Auyero, Elisabeth Jay Friedman, Dawn King, Steven Levitsky, Fiona Macaulay, Vicky Murillo, David Samuels, Kurt Weyland e a diversos revisores anônimos por seus comentários e suas sugestões úteis. Agradeço muito a Kyle Saunders por sua ajuda com a análise estatística e sua interpretação. Os bibliotecários do Centro de América Latina, da Universidade de Oxford, foram muito solícitos ao facilitarem minha necessidade de ler centenas de exemplares do Latin American Weekly Report.
} 
fios mais sérios vieram de participantes civis, no Legislativo, nas ruas ou em ambos. Após o exame do conjunto completo, considero que os presidentes destituídos do poder tinham uma tendência maior a estarem pessoalmente implicados em escândalos, a seguirem políticas neoliberais e a não terem maioria no Congresso do que seus congêneres não contestados. A presença ou ausência de protestos populares de rua desempenhava, então, um papel central no sentido de determinar que presidentes realmente cairiam. A conclusão suscita a questão de determinar se esses padrões regionais tendem a prevalecer no caso de outros regimes presidenciais.

\section{Presidencialismo e quedas presidenciais}

O contraste entre regimes presidenciais e parlamentares é uma das dicotomias fundamentais da política democrática comparativa, com debates permanentes sobre qual deles

10 é mais estável ou mais democrático ${ }^{1}$. Este artigo examina apenas os regimes presidenciais, já que o dilema central de finais prematuros para mandatos executivos só é possível no presidencialismo. Ele tem como ponto de partida a definição clássica de presidencialismo de Sartori: um regime é presidencial "se, e apenas se, o Chefe de Estado: 1) resulta de eleição popular; 2) durante o seu mandato preestabelecido, ele ou ela não pode ser afastado pelo voto parlamentar; e 3) lidera ou de outra maneira dirige os governos que ele ou ela nomeia"2. Linz destaca duas características que são, desta forma, comuns a todos os sistemas presidenciais, ou seja, que um presidente eleito por via direta goza de legitimidade democrática individual e é eleito para um mandato rigorosamente fixado ${ }^{3}$. Essas definições formam a funda-

\footnotetext{
${ }^{1}$ Linz e Valenzuela, 1994; Mainwaring e Shugart, 1997; Przeworski, Alvarez, Cheibub e Limongi, 2000.

2 Sartori, 1994, p. 84.

${ }^{3}$ Linz, 1994, p. 6. 
mentação consensual da maior parte das investigações que se seguem sobre o presidencialismo e seus efeitos.

Em oposição a essas expectativas, a emergência regular de desafiantes, que exigem o afastamento prematuro dos presidentes do cargo, sugere que as eleições diretas na América do Sul não dão consistentemente aos presidentes uma legitimidade que dure o tempo devido. Este estudo leva em consideração apenas os presidentes que foram escolhidos pelo voto popular de seus povos e que, assim, em determinada época, possuíam evidências da legitimidade individual de sua base eleitoral para serem chefes de Estado e de governo. De 40 presidentes tais como estes, cujos mandatos terminaram por volta de 2003, 16 deles $(40 \%)$ enfrentaram contestações à sua permanência no cargo e 9 (23\%) com seus mandatos "fixos" terminados prematuramente (ver Tabela 1). Os presidentes do Equador e da Bolívia também caíram desde 2003, e Chávez, da Venezuela, mal sobrevivem aos desafios ao seu governo. Em face desses acontecimentos, é óbvio que os presidentes sul-americanos não podem assumir que terão o exercício de um mandato fixo e determinado.

A expressão "queda presidencial" é utilizada neste trabalho para identificar todas as vezes em que presidentes eleitos deixaram o cargo antes de completar seus mandatos, quer tenham renunciado ou sofrido impeachment, ou tenham sido forçados, de alguma forma, a deixar o cargo. A palavra "contestação" envolve uma ação concreta no sentido de convencer o presidente a renunciar ou a deixar o cargo antes do fim do mandato. As diversas contestações e quedas são consideradas em conjunto, com base na teoria de que todos são desvios do mandato previsto e fixo do presidencialismo.

Uma observação crucial sobre esses casos é a de que todos resultaram em novos presidentes civis num curto prazo. Em outras palavras, as quedas presidenciais, tal como discutidas aqui, são mudanças dentro do regime. Não são rupturas de regime, que pressupõem uma transição 
Repensando o presidencialismo: contestações e quedas de presidentes na América do Sul

Tabela 1 - Destinos de presidentes da América do Sul, 1978-2003*

\begin{tabular}{|c|c|c|c|c|c|}
\hline País/Presidente & $\begin{array}{l}\text { Data do } \\
\text { mandato }\end{array}$ & $\begin{array}{c}\text { Minoria } \\
\text { parlamentar }\end{array}$ & $\begin{array}{l}\text { Escândalos } \\
\text { relacionados }\end{array}$ & $\begin{array}{c}\text { Políticas } \\
\text { neoliberais }\end{array}$ & Fim do mandato \\
\hline \multicolumn{6}{|l|}{ Argentina } \\
\hline Alfonsín & $1983 / 1989$ & $\operatorname{sim}$ & não & não & Renunciou \\
\hline Menem & 1989/1995 & $\operatorname{sim}$ & não & $\operatorname{sim}$ & Completou \\
\hline Menem & 1995/1999 & $\operatorname{sim}$ & $\operatorname{sim}$ & $\operatorname{sim}$ & Completou \\
\hline De la Rúa & $1999 / 2001$ & $\operatorname{sim}$ & não & $\operatorname{sim}$ & Renunciou \\
\hline \multicolumn{6}{|l|}{ Bolívia } \\
\hline Paz Estenssoro & 1985/1989 & $\operatorname{sim}$ & não & $\operatorname{sim}$ & Completou \\
\hline Paz Zamora & 1989/1993 & $\operatorname{sim}$ & $\operatorname{sim}$ & $\operatorname{sim}$ & Completou \\
\hline Sanchez de Lozada & 1993/1997 & $\operatorname{sim}$ & $\operatorname{sim}$ & $\operatorname{sim}$ & Completou \\
\hline Sanchez de Lozada & $2002 / 2003$ & $\operatorname{sim}$ & não & $\operatorname{sim}$ & Renunciou \\
\hline \multicolumn{6}{|l|}{ Brasil } \\
\hline Collor & 1990/1992 & $\operatorname{sim}$ & $\operatorname{sim}$ & $\operatorname{sim}$ & $\begin{array}{l}\text { Sofreu impeachment e } \\
\text { renunciou }\end{array}$ \\
\hline Cardoso & 1995/1998 & $\operatorname{sim}$ & não & $\operatorname{sim}$ & Contestado e completou \\
\hline Cardoso & $1999 / 2002$ & $\operatorname{sim}$ & não & $\operatorname{sim}$ & Contestado e completou \\
\hline \multicolumn{6}{|l|}{ Chile } \\
\hline Aylwin & 1990/1994 & $\operatorname{sim}$ & não & $\operatorname{sim}$ & Completou \\
\hline Frei & $1994 / 2000$ & $\operatorname{sim}$ & não & $\operatorname{sim}$ & Completou \\
\hline \multicolumn{6}{|l|}{ Colômbia } \\
\hline Turbay & 1979/1982 & não & não & não & Completou \\
\hline Betancur & 1982/1986 & $\operatorname{sim}$ & não & $\operatorname{sim}$ & Completou \\
\hline Barco & $1986 / 1990$ & $\operatorname{sim}$ & não & não & Completou \\
\hline Gavíria & 1990/1994 & não & não & $\operatorname{sim}$ & Completou \\
\hline Samper & 1994/1998 & não & $\operatorname{sim}$ & não & Contestado e completou \\
\hline Pastrana & $1998 / 2002$ & $\operatorname{sim}$ & $\operatorname{sim}$ & $\operatorname{sim}$ & Completou \\
\hline \multicolumn{6}{|l|}{ Equador } \\
\hline Febres Cordero & $1984 / 1988$ & $\operatorname{sim}$ & não & $\operatorname{sim}$ & Contestado e completou \\
\hline Borja & 1988/1992 & $\operatorname{sim}$ & não & $\operatorname{sim}$ & Contestado e completou \\
\hline Duran Ballen & 1992/1996 & $\operatorname{sim}$ & $\operatorname{sim}$ & $\operatorname{sim}$ & Completou \\
\hline Bucaram & 1996/1997 & $\operatorname{sim}$ & $\operatorname{sim}$ & $\operatorname{sim}$ & $\begin{array}{l}\text { Forçado a sair e } \\
\text { declarado incapaz }\end{array}$ \\
\hline Mahuad & $1998 / 2000$ & $\operatorname{sim}$ & $\operatorname{sim}$ & $\operatorname{sim}$ & $\begin{array}{l}\text { Golpe civil/militar e } \\
\text { abandonou a função }\end{array}$ \\
\hline
\end{tabular}




\begin{tabular}{|c|c|c|c|c|c|}
\hline País/Presidente & $\begin{array}{l}\text { Data do } \\
\text { mandato }\end{array}$ & $\begin{array}{c}\text { Minoria } \\
\text { parlamentar }\end{array}$ & $\begin{array}{l}\text { Escândalos } \\
\text { relacionados }\end{array}$ & $\begin{array}{c}\text { Políticas } \\
\text { neoliberais }\end{array}$ & Fim do mandato \\
\hline \multicolumn{6}{|l|}{ Paraguai } \\
\hline Rodriguez & $1989 / 1993$ & não & não & $\operatorname{sim}$ & Completou \\
\hline Wasmosy & 1993/1998 & $\operatorname{sim}$ & $\operatorname{sim}$ & $\operatorname{sim}$ & Contestado e \\
\hline & & & & & completou \\
\hline Cubas & 1998/1999 & não & $\operatorname{sim}$ & $\operatorname{sim}$ & Renunciou e enfrentou \\
\hline \multicolumn{6}{|l|}{ Peru } \\
\hline Belaúnde & $1980 / 1985$ & não & não & $\operatorname{sim}$ & Completou \\
\hline García Pérez & $1985 / 1990$ & não & $\operatorname{sim}$ & não & Completou \\
\hline Fujimori & $1990 / 1995$ & $\operatorname{sim}$ & não & $\operatorname{sim}$ & Sofreu impeachment e \\
\hline & & & & & completou \\
\hline Fujimori & $1995 / 2000$ & não & não & $\operatorname{sim}$ & Completou \\
\hline Fujimori & $2000 / 2000$ & $\operatorname{sim}$ & $\operatorname{sim}$ & $\operatorname{sim}$ & Renunciou e foi \\
\hline & & & & & declarado incapaz \\
\hline \multicolumn{6}{|l|}{ Uruguai } \\
\hline Sanguinetti & 1985/1990 & $\operatorname{sim}$ & não & não & Completou \\
\hline Lacalle & $1990 / 1995$ & $\operatorname{sim}$ & não & $\operatorname{sim}$ & Completou \\
\hline Sanguinetti & $1995 / 2000$ & $\operatorname{sim}$ & não & $\operatorname{sim}$ & Completou \\
\hline \multicolumn{6}{|l|}{ Venezuela } \\
\hline Herrera Campíns & $1979 / 1984$ & $\operatorname{sim}$ & não & não & Completou \\
\hline Lusinchi & 1984/1989 & não & não & não & Completou \\
\hline Pérez & $1989 / 1993$ & $\operatorname{sim}$ & $\operatorname{sim}$ & $\operatorname{sim}$ & Sofreu impeachment \\
\hline & & & & & e abandonou a função \\
\hline Caldera & 1994/1999 & $\operatorname{sim}$ & não & $\operatorname{sim}$ & Completou \\
\hline Chávez & $1999 / 2000$ & $\operatorname{sim}$ & não & não & Completou \\
\hline
\end{tabular}

*A lista não inclui presidentes cujos mandatos terminaram prematuramente devido a razões de saúde ou morte nem presidentes que não tinham encerrado suas gestões em 2003. Na seção "Por que os presidentes são contestados" explica-se a codificação dos casos. 
para ou de um regime civil. De maneira uniforme, os vicepresidentes e os líderes legislativos assumiram mandatos constitucionais na qualidade de presidentes após as quedas presidenciais. Dois desafios efetivamente incluíram protagonistas militares - Equador (2000) e Venezuela (2002) -, mas também rapidamente se transformaram em regimes civis. A natureza civil das quedas presidenciais é especialmente digna de nota, já que os participantes nãocivis ameaçaram presidentes durante este período sem êxito. A expectativa de Linz, no sentido de que os militares assumiriam como poder moderador para gerir os conflitos entre o Executivo e o Legislativo, foi refutada de maneira um tanto dramática ${ }^{4}$.

Conseqüentemente, meu enfoque concentra-se nas contestações a presidentes por parte de civis, tanto no Legislativo quanto na sociedade civil. Muitos estudos de quedas de presidentes na América do Sul centraram-se em negociações 14 das elites, que derrubam presidentes em um país, tratando os protestos populares de rua como pressão sobre as elites ${ }^{5}$. Outros, contudo, atribuem ao desempenho do protesto de massa um papel essencial numa queda presidencial específica ${ }^{6}$. Enquanto esses estudos provêem informações valiosas sobre o desenrolar dos momentos de crise, argumento que o estudo das quedas presidenciais precisa ser aperfeiçoado de duas formas, a fim de que se compreenda o fenômeno geral na América do Sul, e talvez além dela.

Em primeiro lugar, esses estudos sofrem o erro metodológico de escolher apenas na variável dependente o ponto

\footnotetext{
${ }^{4}$ Linz, 1994, 2003b, p. 7.

${ }^{5}$ Carey, 2003b, pp. 983-1.006; Schamis, 2002, pp. 81-94. A revisão de Carey de uma série de casos recentes também pressupõe que as relações Executivo-Legislativo sejam essenciais. Carey, 2003a, pp. 22-25.

${ }^{6}$ Abente-Brun, 1999, pp. 93-100; García Calderón, 2001, pp. 59-73; Weyland, 1993, pp. 1-37. Na conclusão de seu estudo comparativo de um "novo presidencialismo", Pérez-Liñan reconhece o papel aparente do protesto popular, mas não o analisa (cf. Pérez-Liñan, 2003b, pp. 149-164).
} 
de vista da compreensão das causas de quedas presidenciais. Analisam casos em que os presidentes caíram e faltam-lhes casos correspondentes, em que os presidentes permaneceram em exercício durante todo o mandato, apesar dos esforços para expulsá-los. Este artigo utiliza um instrumento de estudo de movimentos sociais, a análise dos eventos de protesto, para corrigir esse problema metodológico. Esta análise vale-se de fontes da mídia para documentar a ocorrência de formas não-convencionais de ação coletiva, como um primeiro passo, para, em seguida, avaliar as causas ou as conseqüências dessa ação ${ }^{7}$. Usei essa técnica para documentar todas as 16 vezes, desde 1978, em que a população ou as elites do Congresso atuaram no sentido de exigir fins prematuros dos mandatos presidenciais.

Tabela 2 - Contestações civis a presidentes sul-americanos eleitos por voto popular, 1978-2003

\begin{tabular}{|c|c|c|c|}
\hline Desfecho & $\begin{array}{c}\text { Manifestações } \\
\text { populares de rua }\end{array}$ & $\begin{array}{l}\text { Manifestações } \\
\text { de rua e ação do } \\
\text { Legislativo }\end{array}$ & $\begin{array}{c}\text { Ação do } \\
\text { Legislativo }\end{array}$ \\
\hline $\begin{array}{l}\text { Presidentes } \\
\text { que caíram }\end{array}$ & $\begin{array}{l}1989 \text { Argentina } \\
\text { 1999/2000 Equador } \\
2001 \text { Argentina } \\
2003 \text { Bolívia }\end{array}$ & $\begin{array}{l}1992 \text { Brasil } \\
\text { 1992/1993 Venezuela } \\
1997 \text { Equador } \\
\text { 1998/1999 Paraguai } \\
2000 \text { Peru }\end{array}$ & \\
\hline $\begin{array}{l}\text { Presidentes que } \\
\text { permaneceram } \\
\text { em seus cargos }\end{array}$ & 1995 Brasil & 1999 Brasil & $\begin{array}{l}1987 \text { Equador } \\
1991 / 1992 \text { Peru } \\
1992 \text { Equador } \\
1994 \text { Paraguai } \\
\text { 1995/1996 Colômbia }\end{array}$ \\
\hline
\end{tabular}

A maioria dessas tentativas malsucedidas são, em grande parte, esquecidas, já que não tiveram êxito, mas são tão fundamentais para entender as quedas presidenciais quanto

\footnotetext{
${ }^{7}$ Koopmans e Rucht, 1999, pp. 123-130.
} 
as bem-sucedidas. A primeira seção empírica, abaixo, começa com três motivos de contestação identificados por indução: as diretrizes econômicas neoliberais do presidente; seu envolvimento pessoal em escândalos; e seu status minoritário. Em seguida, são examinadas todas as 40 presidências: os três motivos são aparentes fatores de risco para quem pretende terminar os seus mandatos, tendo em vista que os governantes contestados, ou que caíram, compartilham desproporcionalmente tais características, se comparados com o conjunto completo de presidentes.

Meu segundo argumento aponta no sentido de que a presença ou ausência de protestos populares de rua é basilar para os resultados do desafio: enquanto tanto elites políticas quanto massas populares têm tentado afastar presidentes prematuramente, todas as mobilizações bem-sucedidas de quedas presidenciais incluíram participantes da sociedade civil, que exigiam nas ruas a saída dos presidentes ${ }^{8}$. Como se depreende da Tabela 2, com seu quadrante vazio, fracassaram todas as cinco tentativas de afastar presidentes que ocorreram exclusivamente no Legislativo. Essas observações sugerem que o protesto de rua é decisivo, ao menos nas etapas finais das quedas presidenciais. Os protestos pelos participantes da sociedade civil, com ou sem ação legislativa paralela, parecem ser o poder moderador dos novos regimes civis. Isso marca a reversão de padrões anteriores, em que os militares desempenhavam esse papel na região, com suas intervenções freqüentemente desencadeadas por protestos populares de rua. A segunda seção empírica discute a forma pela qual o protesto popular de rua contribui para as quedas presidenciais, seja diretamente, seja acompanhada de uma ação legislativa.

\footnotetext{
${ }^{8}$ Emprego o termo "sociedade civil" de uma forma estritamente descritiva neste caso, para indicar que esses não são participantes do Estado. Não faço hipóteses normativas de que sejam necessariamente civis ou democráticos, mas trato a questão como empírica.
} 
A importância central do protesto das massas populares nas quedas presidenciais sugere a necessidade de maior reflexão sobre o papel do público no presidencialismo. A literatura acerca da consolidação democrática geralmente tem-se voltado rápido demais para as instituições, ao invés de considerar as relações Estado-sociedade, a fim de explicar os resultados políticos ${ }^{9}$. Isso se aplica, também, aos estudos do presidencialismo, apesar de que uma das características essenciais dos sistemas presidenciais é o mandato individual que o presidente recebe da população sob a forma eleitoral ${ }^{10}$. As discussões sobre o presidencialismo deixaram de examinar as formas pelas quais a população pode evidentemente retirar o mandato que concede, um fenômeno que se está tornando mais comum no cronograma da consolidação democrática.

A maior parte dos estudos sobre o presidencialismo originou-se da obra clássica de Juan Linz, que compara presidencialismo com parlamentarismo. Quando Linz ajudou a lançar o estudo comparativo desses sistemas nos anos 1980, ele estava certo em argumentar que as instituições tinham sido pouco estudadas e que era necessário atribuir-lhes um

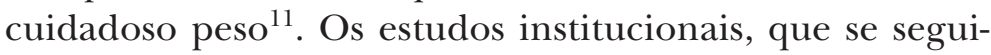
ram, trouxeram muitas sugestões. Os fatores institucionais da elite são claramente essenciais na política de rotina - 77\% dos recentes presidentes da América do Sul não caíram -, e numerosos artigos continuam a mapear áreas interessantes de pesquisa para esse tipo de política ${ }^{12}$.

No entanto, no caso de política não-rotineira, as análises institucionais são menos úteis ${ }^{13}$. As contestações a presi-

\footnotetext{
${ }^{9}$ Yashar, 1999, pp. 76-106.

${ }^{10}$ Stokes, 2001.

${ }^{11}$ Linz, 1994, pp. 3-5.

${ }^{12}$ Amorim Neto, 2006; Cheibub, 2002, pp. 284-312; Samuels e Shugart, 2003, pp. 33-60.

${ }^{13}$ Weyland, 2002, pp. 57-85.
} 
dentes, feitas pela sociedade, apresentam um dilema para as análises institucionais de rotina, devastando o que Barbara Geddes identifica como as duas hipóteses-padrão simplificadoras para entender a política nos regimes democráticos: "em primeiro lugar, que as autoridades querem permanecer no cargo; em segundo lugar, que a melhor estratégia para fazê-lo é dar aos eleitores o que desejam"14. Quando os eleitores querem que o presidente saia do cargo, as hipóteses-padrão simplificadoras são, evidentemente, inadequadas para entender os acontecimentos políticos. A política passa a ser uma questão de os presidentes encontrarem um equilíbrio entre duas motivações essenciais, agora em contradição. A evidência deste artigo sugere que os fatores que explicam resultados políticos extraordinários, tais como quedas de presidentes - ou a continuidade de seus mandatos -, devem incluir o público na qualidade de formador atuante da política, principalmente quanto à descoberta deste ponto de equilíbrio.

\section{Os eventos de protesto na contestação a presidentes}

Neste trabalho, as contestações são identificadas pela técnica de análise dos eventos de protesto, que se utiliza de fontes de mídia impressa para rastrear as ocorrências de eventos de protesto, valendo-se de procedimentos de codificação padronizados ${ }^{15}$. Os dados sobre as contestações aqui apresentados baseiam-se em 25 anos de exemplares semanais da publicação Latin American Weekly Report (Lawr). O Weekly Report autodenomina-se um provedor de "súmulas orientadas para riscos, concisos e oportunos" ${ }^{" 16}$. Esta missão significa que o Lawr está muito atento aos eventos de protesto

\footnotetext{
${ }^{14}$ Geddes, 2003.

${ }^{15}$ Koopmans e Rucht, 1999.

${ }^{16}$ Disponível em: www.latinnews.com/lwr/LAWR2315.asp. Citações a números específicos seguem o formato do Report: WR-00-03 é o terceiro número do Weekly Report em 2000.
} 
e ao que tende a chamar de "levantes sociais", assim como a eventos políticos inusitados da elite, tais como processos de impeachment. O formato semanal significa que ela relata apenas os eventos mais importantes desse tipo, criando as habituais linhas de prever eventos maiores e mais dramáticos. Já que o tema que nos interessa aqui são as tentativas de derrubar presidentes, o Lawr capta os eventos relevantes.

Uma questão da análise de eventos de protesto é determinar o que conta como protesto, ou, neste caso, como contestação. Para os participantes da sociedade civil, este estudo focaliza mobilizações de massa relatadas que colocam multidões na rua ${ }^{17}$. Da mesma forma, no caso de ações do Congresso, procurei relatórios da programação de processos formais de impeachment ou de outros esforços concretos no sentido de afastar os presidentes. Uma decisão codificada de maneira correlata envolveu a forma de saber se determinado protesto ou ação do Congresso realmente visava a retirar do cargo um presidente. Neste sentido, eu simplesmente tirei o objetivo relatado do Lawr, que sempre especificava, sem rodeios, qual era ele: reforma agrária, salários mais altos, ou - no caso, o que interessa aqui - a queda do presidente. Os observadores de marchas de protesto de milhares de pessoas irão entender que essas caracterizações inevitavelmente escondem as diferentes razões que fazem os indivíduos irem para as ruas, mas, geralmente, há uma predominância de evidência sobre o traço de união do grupo.

\section{Por que os presidentes são contestados}

Esta seção identifica e analisa as características que separam os presidentes contestados de seus congêneres regionais. Uma avaliação indutora dos atuais desafios a presidentes

\footnotetext{
${ }^{17} \mathrm{~A}$ utilização em larga escala de protestos de rua contrasta com os tipos mais institucionalizados de atividade que têm surgido em muitos setores de movimentos sociais desde o retorno ao governo civil. Ver Friedman e Hochstetler, 2002, pp. 21-42.
} 
mostra que três temas motivaram virtualmente quase todas as campanhas para afastar presidentes prematuramente. Para os participantes da sociedade civil, a insatisfação com as diretrizes econômicas e seus resultados foi a razão mais comum para as contestações a presidentes. As acusações de corrupção, quando vinculadas à figura do próprio presidente, foram importantes para ambos os conjuntos de participantes. Os legisladores que se defrontavam com presidentes com minoria no Congresso também se utilizaram de contestações para resolver pela luta relações interpoderes, acompanhando as muitas mudanças formais das Constituições neste período. Esta seção trata de cada uma dessas razões para contestar-se o presidente, descrevendo os tipos de desafios baseados em cada um e examinando a incidência de cada fator no conjunto completo de 40 presidentes (ver Tabela 1, pp. 12-13). Nas conclusões desta seção, apresento resultados probabilísticos de um modelo 20 de regressão logística das variáveis dependentes, os quais mostram que a presença de escândalos produz os efeitos maiores nas chances de contestações aos presidentes e de queda presidencial.

\section{Políticas econômicas}

A disseminação regional de políticas orientadas para o mercado durante este período gerou intensos conflitos políti$\cos$ e econômicos ${ }^{18}$. Enquanto alguns queriam as políticas neoliberais, os protestos contra elas enchiam repetidamente as ruas das capitais sul-americanas. Muitos desses protestos não se transformaram em protestos contra os presidentes que permaneciam no poder. Contudo, apenas duas das coalizões desafiadoras baseadas nos protestos de rua (19981999 - Paraguai e 2000 - Peru) efetivamente não protestavam contra as políticas econômicas dos presidentes, com o

\footnotetext{
${ }^{18}$ Wise, Roett e Paz, 2003.
} 
padrão característico de meses de protestos antieconômicos subitamente explodindo numa insistência no afastamento do presidente. Assim, sete meses de protestos contínuos contra a política econômica de De la Rúa na Argentina transformaram-se em clamores para que ele se afastasse, que duraram apenas duas semanas antes de sua renúncia. Dez presidentes, que adotaram políticas neoliberais, foram alvo de contestações baseadas em protestos de rua, enquanto apenas um presidente não neoliberal (Alfonsín, na Argentina, em 1989) enfrentou protestos de rua.

Nessas contestações, a escala de demanda parece estar relacionada aos participantes envolvidos. Os movimentos baseados em protestos populares de rua contra presidentes, motivados na economia, eram, de modo geral, preparados por organizações da sociedade civil. Os sindicatos e os estudantes eram a essência de todas essas mobilizações, com as principais organizações sindicais repetidamente na linha de frente. Quando os protestos envolviam apenas sindicatos e estudantes, eles enfocavam demandas econômicas mais específicas. Mobilizações mais amplas, que realmente insistiram para o presidente se afastar prematuramente, sempre tinham participantes adicionais, inclusive cidadãos individuais que eram instados a se juntarem ao movimento. As organizações adicionais variavam segundo o país, mas outros participantes comuns eram os camponeses, organizações religiosas e associações de moradores. No Equador e na Bolívia, grupos indígenas têm sido atores centrais, enquanto no Brasil e na Venezuela, às vezes, participavam associações profissionais. Grupos empresariais também apoiaram todas as mobilizações da sociedade civil, até e inclusive a tentativa de afastar Bucaram Ortiz (Equador) em 1997; desde então, eles têm sido apenas uma parcela dos desafios a Chávez na Venezuela.

Os presidentes contestados tendiam muito mais a seguirem políticas econômicas neoliberais do que políticas popu- 
listas ou de segurança - 10 contra $1^{19}$. Este resultado desproporcional, de certa forma, melhora quando se considera o conjunto completo de presidentes depois de 1978, já que mais presidentes seguiram políticas neoliberais. Dos 31 presidentes neoliberais, 14 foram contestados (45\%) e 8 caíram (26\%). Esses números são mais elevados do que os $33 \%$ dos presidentes voltados para a segurança (3 de 9) que foram contestados, e do que os $11 \%$ (1) que foram afastados, mas muitos presidentes sobreviveram a esse fator de risco. Para completar o quadro, ocorreram também protestos contra o presidente no único país da região que mais claramente rompeu com o liberalismo, a Venezuela.

\section{Corrupção e outros escândalos}

Os Congressos e os participantes da sociedade civil freqüentemente se uniam para contestar presidentes, quando haviam boas provas de corrupção ou de escândalo que envolviam o próprio presidente. Os Congressos davam início a numerosas investigações nesses casos, usando os recursos e os procedimentos de seu poder no governo. Em sua maioria, os legisladores limitavam-se aos processos legais, em suas tentativas de afastar presidentes com base em corrupção, e os cidadãos apoiavam os seus esforços.

O processo formal de impeachment era o mais comum, iniciado em 9 das 11 contestações legislativas a presidentes, e ameaças de impeachment foram as situações mais freqüentes $^{20}$. No entanto, a maior parte das legislaturas eventualmente utilizou-se de vários procedimentos de afastamento mais ou menos constitucionais nesses casos. Apenas o impeachment quase que "de livro" do Brasil, em 1992, realmente pas-

\footnotetext{
${ }^{19}$ Dados de 1982-1995, de Stokes, 2001, pp. 14-15. Os dados relativos a outros anos são da revista The Economist. A coluna está marcada como "sim" para presidentes cuja orientação política no governo era neoliberal; "não" para orientação política no sentido do que o Economist chama de "populismo".

${ }^{20}$ Ver também: Baumgartner, 2003; Pérez-Liñan, 2003a.
} 
sou por todas as etapas legais, desde a investigação ao pedido formal de impeachment por uma das casas legislativas até o julgamento final por outra. Em diversos casos, os Congressos eventualmente optavam por processos de afastamento que não exigiam as supermaiorias do impeachment, afastando presidentes por abandono de cargo (1993 - Venezuela, 2000 - Equador), por incapacidade mental (1997 - Equador) e incapacidade moral (2000 - Peru). A utilização desses tipos de procedimento pode parecer muito distante do impeachment, que, freqüentemente, é concebido como uma espécie de processo de afastamento legal não-partidário em vista de algum comportamento inadequado do presidente. Pelo contrário: o impeachment sempre tem sido "fundamentalmente um processo político do início ao fim"21, tornando as distinções entre esses tipos de afastamento menos importantes. A tradução espanhola mais comum de impeachment, juicio político, torna claro o duplo sentido da palavra. Literalmente julgamento político, juicio político pode indicar tanto a instrução com base constitucional em que um poder constitucional, o Legislativo, deve julgar o caso extraordinário do afastamento legal de uma figura política, quanto os julgamentos que têm motivação política.

Ambos os significados são relevantes para os recentes desafios dos legislativos aos presidentes na América do Sul. O impeachment brasileiro de Collor em 1992 é o melhor exemplo de um processo constitucional pleno. O afastamento do presidente Pérez, da Venezuela, ilustra ambos os sentidos: enquanto ele foi devidamente impedido e afastado do cargo pela utilização escusa que fez de um fundo do tipo "caixa 2" de US\$ 17 milhões, esta foi simplesmente a última das cinco tentativas feitas por um Congresso politicamen-

\footnotetext{
${ }^{21}$ Baumgartner, 2003, p. 5. Até mesmo nos Estados Unidos, fortemente institucionalizados, sete presidentes americanos, de Jackson a Clinton, enfrentaram contestações de impeachment a suas presidências, quase todas com base em acusações politizadas feitas por câmaras controladas pela oposição. Ver Perkins, 2003.
} 
te hostil no sentido de afastá-lo, num período de dezoito meses. Além disso, depois que Pérez deixou o governo para aguardar julgamento, o Congresso afastou-o permanentemente antes do início do julgamento, com base na tese constitucional questionável de abandono do cargo ${ }^{22}$.

Os cidadãos freqüentemente encenavam manifestações de massa em apoio a essas tentativas do Congresso baseadas em corrupção, a maior delas com milhões de brasileiros, entre os que insistiam na saída de Collor. Com base em comprovações não-sistemáticas dos Weekly Reports, a evidência de corrupção pessoal também parece ligada a baixos índices de aprovação pública, que contribuíram para os protestos de rua. Dessa forma, apenas $8 \%$ dos brasileiros consideravam o regime de Collor como bom no início do ano de seu declínio, enquanto Pérez, da Venezuela, baixou para o índice histórico de $6 \%$ de aprovação ${ }^{23}$. $\mathrm{O}$ rápido impacto da corrupção na opinião pública pode 24 ser visto no Peru, onde o índice de aprovação de Fujimori caiu de $43 \%$ para $16 \%$, depois que um vídeo mostrou claramente a corrupção de sua administração, apesar da longa boa vontade do povo peruano no sentido de aceitar seus abusos de poder ${ }^{24}$.

Avaliar a incidência global de corrupção e de escândalos dos presidentes da região é tão desafiador para o analista quanto para os cidadãos sul-americanos. As acusações são quase que permanentes, e uma ação judicial contra o presidente não é nem necessária nem suficiente para provar maus procedimentos. A estratégia de pesquisa, no caso presente, que considera o presidente como pessoalmente corrupto, quando as acusações merecem suficiente crédito para aparecerem como a principal manchete da semana no Lawr, aproxima-se do nível doméstico da crença de que

\footnotetext{
${ }^{22}$ WR-93-36

${ }^{23}$ Sobre o Brasil, ver WR-92-01; Venezuela, ver Romero, 1997, p. 15

${ }^{24}$ WR-00-40
} 
o presidente é corrupto ${ }^{25}$. Esta crença, quer verdadeira ou não, é a possível fundamentação das contestações. A ausência de relatos de corrupção parece proteger os presidentes, uma vez que apenas 8 de 26 presidentes (31\%) desse tipo foram contestados, e só 3 presidentes, presumivelmente não-corruptos, caíram ${ }^{26}$. Em contraposição, enquanto a ação contra presidentes corruptos, às vezes, é rápida, o conjunto maior de casos mostra que muitos presidentes sobrevivem a graves alegações de corrupção pessoal: 6 de 14 (43\%) não contestados durante os seus mandatos, e apenas 6 tendo sido afastados prematuramente do cargo.

\section{Presidentes com minoria no Congresso}

Nos legislativos, as contestações dirigiam-se, em grande parte, a presidentes com minoria no Congresso, com 14 contestações a presidentes com minoria e 2 com maioria. Os líderes da oposição estavam ansiosos para fazer acusações de corrupção contra presidentes que estivessem pessoalmente implicados, como já foi discutido. Na ausência desses relatórios, eles geralmente recorriam a algum tipo de alegação acerca de comportamento presidencial inconstitucional com relação ao Congresso ou outras instituições governamentais (Equador - 1987, 1992; Peru - 1991-1992; Paraguai - 1998-1999). Muitas dessas contestações a presidentes com

\footnotetext{
${ }^{25} \mathrm{Na}$ Tabela 1, "sim" significa que o presidente estava pessoalmente implicado nas acusações de motivos para impeachment, normalmente corrupção financeira. Esta é uma estimativa muito conservadora do nível de corrupção, já que o Lawr não publica acusações de fontes secundárias e outras. Além disso, deve-se observar que um presidente só é rotulado de corrupto se isso ocorre durante o mandato real em que ele possa ter sido contestado. Dessa forma, por exemplo, Lusinchi, na Venezuela, não é rotulado como corrupto, já que não houve relato de sua corrupção no Lawr durante seu exercício no cargo, mesmo que ele tenha sido acusado posteriormente de corrupção.

${ }^{26}$ Dois eram Alfonsín e De la Rúa. O outro foi Sanchez de Lozada (segundo mandato) na Bolívia, embora tenha havido relato de corrupção em seu primeiro mandato.
} 
minoria tinham motivações claramente políticas, sendo que o Equador deu vários exemplos dignos de nota. Uma tentativa de impeachment em 1992, por exemplo, foi justificada por objeções do Congresso a um projeto de lei sobre reforma monetária e ao fato de o presidente Borja referir-se a membros do Congresso como "um bando de parasitas" 27 . Os presidentes do Equador também se mostraram bastante duros em seu trato com o Congresso. Febres Cordero, que rechaçou uma tentativa de afastamento em 1987, lançou gás lacrimogêneo no Congresso e mandou tanques para o prédio do tribunal, a fim de bloquear vários juízes nomeados pelo Congresso ${ }^{28}$.

O público freqüentemente ficava indiferente a esse tipo de contestação do Congresso, com um aumento acentuado da aprovação pública após o autogolpe de Fujimori em 1992, como o exemplo mais notável ${ }^{29}$. O voto do Congresso para o seu impeachment foi completamente ignorado. Em 1999, os paraguaios concordaram que, realmente, o presidente Cubas havia ultrapassado os limites do comportamento constitucional, principalmente após o assassinato de seu vice-presidente, ao se aglutinarem "para proteger o prédio do Congresso" 30 .

De modo geral, os presidentes cujos partidos tinham minoria no Congresso apresentavam uma tendência maior tanto para serem contestados por atores civis quanto para caírem $^{31}$. Essa relação mantém-se, mesmo se considerarmos

\footnotetext{
${ }^{27}$ WR-92-17.

${ }^{28}$ Conaghan, Malloy e Abugattas, 1990, pp. 3-30; Isaacs, 1991, pp. 221-238.

${ }^{29}$ Crabtree, 2001, p. 295.

${ }^{30}$ Lambert, 2000, p. 392 e Abente-Brun, 1999.

${ }^{31}$ Dados de 1978-1997 de Kenney, 2004, pp. 264-266. Com relação a presidentes após 1997, os dados são de www.observatorioelectoral.org, utilizando a metodologia de Kenney: "considera-se que [uma] Presidência tenha tido maioria legislativa se o presidente teve o apoio de uma maioria em cada casa do Congresso durante todo o seu mandato no cargo" (Kenney, 2004, p. 333, nota de rodapé 3). Deve-se observar que essa é uma definição rígida, que não leva em conta coalizões partidárias.
} 
o número muito maior de presidentes da região com minoria no Congresso. Dos 31 presidentes nessas condições de que se tratou neste estudo, $14(45 \%)$ deles foram contestados e $8(26 \%)$ caíram. Nos casos mais raros de 9 presidentes com maioria no Congresso, 2 (22\%) foram contestados e apenas $1(11 \%)$ caiu. O presidente Cubas, afastado no Paraguai, foi o único presidente contestado pelos legisladores de seu próprio partido desde o início, mas o partido Colorado é tão dominante naquele país que a política freqüentemente coloca o partido contra si próprio ${ }^{32}$. A outra contestação foi a de Samper, na Colômbia, em 1995-1996, em que o controle da maioria no Congresso por seu partido, e especialmente da comissão parlamentar de inquérito, foi crucial para sua permanência no cargo $^{33}$. Além disso, 3 ex-presidentes, que foram eventualmente julgados por crimes cometidos durante seus mandatos na presidência - García e Fujimori, no Peru, e Lusinchi, na Venezuela -, podem ter conseguido evitar acusações formais enquanto estavam no cargo, já que detinham maioria no Congresso. Essas experiências sugerem que a contestação e a queda de presidentes estão relacionadas ao fato de terem maiorias legislativas, oferecendo argumentos de apoio à interseção problemática e instável entre sistemas presidenciais e multipartidários ${ }^{34}$. No entanto, esse não é o único fator, já que alguns presidentes com maioria no Congresso foram contestados, e outros, com minoria, não o foram. Os únicos dois países que não tiveram seus presidentes contestados, o Uruguai e o Chile, também não tinham presidentes com maioria no Congresso.

\section{Resumo}

As políticas neoliberais, a corrupção pessoal e o não dispor de maioria no Congresso representam fatores de risco para

\footnotetext{
${ }^{32}$ Lambert, 2000.

${ }^{33}$ Dugas, 2001, pp. 157-174; Kada, 2003, pp. 29-54.

${ }^{34}$ Mainwaring, 1993, pp. 198-228.
} 
os presidentes sul-americanos que desejem completar seus mandatos no cargo. A Tabela 3 resume a predição de probabilidade do modelo de regressão logística para as variáveis dependentes, para contestação e queda presidencial - as quais foram calculadas mediante o uso de Clarify ${ }^{35}$. A Tabela 3 apresenta, primeiro, a predição das chances das variáveis dependentes, calculadas introduzindo variações na variável examinada de zero a um, mantendo constantes as outras variáveis independentes no seu valor mais freqüente ou modal.

Tabela 3 - Estimação de probabilidades de contestação e queda

\begin{tabular}{|l|c|c|}
\hline & Contestação & Queda \\
\hline Probabilidades do caso modal & 38,6 & 16,5 \\
\hline Diferenças nas probabilidades de contestação & & \\
variando: & & \\
Políticas neoliberais & $-11,3$ & $-1,0$ \\
Escândalos & 24,4 & 31,9 \\
Minoria no congresso & $-15,7$ & $-5,0$ \\
\hline
\end{tabular}

O presidente modal da região durante os anos contemplados foi um presidente de minoria, que implementou políticas econômicas neoliberais, e não implicado pessoalmente em escândalos. Na estimação de probabilidades, esse presidente enfrentou 38,6\% de probabilidade de ser contestado e $16,5 \%$ de cair $^{36}$. Presidentes com maioria no Legislativo ou que não seguiram políticas neoliberais poderiam contar com uma pequena redução no risco de serem contestados. Por outro lado, a probabilidade de enfrentar contestações saltou para $63 \%(38,6$

\footnotetext{
35 Tomz, Wittenberg e King, 2000, pp. 347-361.

${ }^{36}$ Visto se tratar de uma população e não de uma amostra, probabilidades constituem o indicador mais importante das relações entre os dados. A tabela dos coeficientes, bem como outros resultados, podem ser disponibilizados pela autora mediante solicitação.
} 
mais 24,4), no caso de presidentes pessoalmente envolvidos em escândalos. Escândalos também incrementaram consideravelmente a probabilidade de queda presidencial prematura, saltando para até $48,4 \%$ (16,5 mais 31,9$)$. As outras variáveis independentes não registram efeitos consideráveis nas probabilidades estimadas de queda presidencial.

\section{Da contestação à queda: 0 papel dos protestos de rua}

Como indica a Tabela 2 (p.15), a presença da população mobilizada, exigindo nas ruas que o presidente saia, parece ser um determinante crucial para que as contestações tenham êxito. Os legisladores que agiram por conta própria foram incapazes ou não tiveram vontade de afastar presidentes. Esta seção discute o papel dos protestos de rua nas quedas presidenciais, como um complemento da ação legislativa e, cada vez mais, como um fenômeno em si.

\section{Protestos de rua e contestações do Legislativo}

Os protestos populares desempenharam um papel central nos resultados das contestações do Congresso a presidentes a partir de 1978 na América do Sul. Enquanto se desenrolavam essas contestações, os legisladores pareciam calcular se as populações tinham maior tendência a puni-los por ação ou inação contra presidentes que, em outro momento, dispunham de suficiente apoio popular para alçá-los ao cargo mais alto do país. Os protestos de rua em larga escala, clamando pela saída do presidente, convenciam os legisladores a se inclinarem a agir contra eles. E o que é mais importante: os protestos transferiam antigos partidários do presidente para a oposição, mesmo contra seus colegas de partido. A força motriz do temor de castigo dos eleitores ficou especialmente evidente no impeachment de Collor no Brasil, em que eleições regionais, despontando no horizonte, selaram o seu destino. Os membros do Congresso não 
apenas votaram o seu impeachment, como se apressaram a fazê-lo antes das eleições ${ }^{37}$.

A ação ou inação institucional também pode contribuir para que o povo se mobilize ou não. No mesmo caso brasileiro, uma decisão-chave do Supremo Tribunal exigia votação pública, reduzindo a capacidade de Collor de comprar apoio secreto, e as comissões parlamentares de inquérito revelaram importantes informações que ajudaram a mobilizar os cidadãos ${ }^{38}$. Outros atores, como a mídia, podem desempenhar o papel investigador, mas as instituições detêm o controle essencial quanto aos seus próprios processos internos. Em diversos outros casos (1992, 1993 - Venezuela; 1997 - Equador; 1998-99 - Paraguai; e 2000 - Peru), as mobilizações de rua também levaram os legisladores a agir contra presidentes que haviam violado as leis na escala da linguagem americana de "altos crimes e delitos". Esses exemplos ilustram a significativa ascensão da responsabili30 dade política que pode restringir os presidentes, historicamente fortes demais, da América do Sul.

Ao mesmo tempo, alguns dos acontecimentos desse período ressaltaram basicamente as fraquezas atuais da linguagem constitucional, das normas democráticas e dos sistemas jurídico e investigador. Em diversos casos em que as contestações falharam (1987 - Equador; 1991-1992 - Peru; e 1994 - Paraguai), a sociedade civil fracassou na tentativa de juntar-se ao clamor para afastar presidentes que quase certamente tinham tido comportamento ilegal. Mais de 50 ONGs colombianas organizaram uma respeitada comissão civil para acompanhar a tentativa de impeachment de Samper em 1995-1996 ${ }^{39}$, e líderes empresariais tentaram organizar a oposição, mas não conseguiram levar as pessoas às ruas.

\footnotetext{
${ }^{37}$ Flynn, 1993, pp. 351-371; Weyland, 1993.

${ }^{38}$ Ver decisão do Supremo Tribunal em Flynn, 1993, p. 364. Sobre as investigações do Congresso, ver Nobre, 1992, pp. 15-19.

${ }^{39}$ Comisión Ciudadana de Seguimiento, 1996.
} 
Neste caso, o partido majoritário de Samper foi capaz de conter uma investigação do Congresso, e a população nunca chegou a ouvir grande coisa das provas contra ele ${ }^{40}$.

A imagem final que emerge dessas contestações é a de uma interação dialética entre as contestações do Legislativo e da população. Esse processo poderia desenvolver-se em uma ação mutuamente fortalecedora, freqüentemente capaz de tirar os presidentes do poder. Nos casos em que a ação legislativa não se defrontou com uma reação popular, a contestação fracassava. Em contrapartida, quando o clamor popular em relação aos presidentes não tinha apoio institucional, as contestações com base nos protestos de rua poderiam prosseguir por si sós e muitas vezes o fizeram com sucesso.

\section{Contestações a presidentes com base em protestos de rua}

Um segundo tipo de contestação a presidentes tem ocorrido basicamente nas ruas, embora possa incluir aliados dos partidos em papéis não-institucionais. Esse tipo de contestação mostra pouca atenção aos procedimentos constitucionais e é decidido por meio de mediação direta entre presidentes e cidadãos. Essas contestações vêm de sociedades que são polarizadas contra o Estado e acabam resultando numa literatura que é polarizada de maneira semelhante. Esta última o é em parte porque esses protestos foram orientados na sua maioria por exigências e acusações que claramente não têm o peso do padrão de ofensas que levariam a um impeachment: políticas ineficazes e impopulares não são ilegais. Esta seção examina a natureza e a dinâmica desse conjunto de contestações e faz reflexões sobre as avaliações divergentes sobre elas.

As contestações de rua a presidentes fornecem algumas das imagens mais gráficas da política recente sul-americana.

\footnotetext{
${ }^{40}$ Kada, 2003.
} 
Os canais de televisão têm mostrado uma cobertura contínua de grandes multidões acampadas do lado de fora de palácios presidenciais, exigindo a renúncia do presidente. As contestações da sociedade civil, que foram suficientemente grandes para merecerem registro no Lawr, tinham, pelo menos, milhares de participantes, e nenhum presidente caiu como reação a mobilizações de rua de menos de 10.000 pessoas. No entanto, mobilizações bastante numerosas não conseguiram afastar presidentes, embora os maiores protestos que fracassaram foram contra Chávez, na Venezuela, e elas ainda podem ter êxito ${ }^{41}$. $\mathrm{O}$ fator mais consistente é a persistência. Nenhuma irrupção de protestos de um único dia convenceu um presidente a sair. Pelo contrário: os manifestantes necessitavam de convicção e organização para pressionar os presidentes por vários dias seguidos, ou, às vezes, com intervalos de meses. Todos os presidentes contestados tiveram tempo para reagir, ao oferecer concessões em matéria de políticas, ou para endurecer suas posições.

Vários presidentes escolheram defender os seus mandatos daquilo que consideravam chantagem dos manifestantes. Após pequenas negociações, eles enviavam forças políticas ou até mesmo militares para limpar as ruas. O predomínio da violência de ambas as partes é uma importante característica dessas contestações e parece estar relacionado ao seu sucesso: negativamente para os presidentes e positivamente para os manifestantes.

A maior parte dos milhões de manifestantes de rua ao longo de décadas marchou pacificamente. Apesar disso, a incivilidade tem sido uma parte regular das mobilizações da sociedade civil. Os líderes de todas as espécies perderam o controle da maioria dos protestos em algum momento. O processo brasileiro de impeachment destaca-se, ainda uma

\footnotetext{
${ }^{41} \mathrm{Na}$ maioria dos casos, não há informações confiáveis quanto ao tamanho exato das mobilizações; as estimativas para a Venezuela em 2002-2003 mostram a faixa mais larga: de dezenas de milhares a um milhão (WR-02-28).
} 
vez, pelo seu ineditismo, já que esta foi a única das nove bem-sucedidas contestações a presidentes que não envolveu nenhuma espécie de violência. Conflitos, saques e incêndios criminosos mancharam quase todos os outros. As barricadas - geralmente não legais, mas não inerentemente violentas - também faziam parte regularmente das mobilizações de protesto na Argentina, na Bolívia e no Equador. Em vários casos, a violência foi maior, como no caso da utilização de bombas com pregos na Bolívia em 2003, que mataram vários soldados $^{42}$. Os golpes de curta duração no Equador em 2000 e na Venezuela em 2002 também foram óbvios excessos de inconstitucionalidade, com alguns participantes da sociedade civil que mostravam uma má vontade preocupante, no sentido de alijar totalmente a civilidade e cooptar aliados militares para pressionar os presidentes a saírem.

A violência dos manifestantes não existe num vácuo, e a incivilidade foi inflamada pela violência e pela repressão do Estado. Os níveis de violência de manifestantes, e o número de manifestantes mortos pelas forças de segurança estavam claramente associados. Até agora, o Brasil e o Equador têm tido contestações inusitadamente não-violentas, tanto da parte dos manifestantes quanto das forças de segurança. Durante cinco mobilizações para quedas presidenciais nos dois países, os manifestantes de rua foram violentos apenas no Equador em 1997, e aquela contestação também envolveu a única morte de um manifestante. $\mathrm{O}$ papel-chave das forças de segurança na determinação dos níveis de violência pode ser visto pelo fato de o golpe do Equador em 2000 ter ocorrido sem derramamento de sangue devido, em grande parte, ao fato de os soldados terem realmente encorajado os manifestantes a ocuparem o prédio do Congresso ${ }^{43}$. Na outra extremidade do espectro, a Argentina e a Venezuela têm

\footnotetext{
${ }^{42}$ WR-03-07; WR-02-15; WR-02-50.

${ }^{41}$ Lucero, 2001.
} 
tido a repressão mais consistentemente letal ao longo deste período, com 25 mortos nas mobilizações contra De la Rúa e até 46 mortes notificadas em seguida ao golpe civil/militar de 2002 na Venezuela ${ }^{44}$. Contestações de rua anteriores, em 1989 (Argentina) e em 1992-1993 (Venezuela), também envolveram inúmeros manifestantes feridos e 16 mortes na Venezuela. A Venezuela e o Paraguai compartilham a infeliz distinção de serem dois locais onde os que apoiavam e os que contestavam os presidentes entraram em choque na rua, elevando os níveis de violência em ambos os países. A contestação da sociedade civil paraguaia a Cubas em 1999, de outro modo, teria sido pacífica. O maior número de mortes notificadas foi na Bolívia em 2003, com até 100 mortos $^{45}$. Apenas Chávez, na Venezuela, sobreviveu a uma contestação, em que as forças de segurança reagiram aos manifestantes com o uso significativo da força e numerosas mortes.

A outra opção dos presidentes é negociar e ofere34 cer concessões em matéria de políticas. Essas negociações foram difíceis, já que a natureza amorfa dos protestos de rua significava que os presidentes raramente encontravam interlocutores que podiam garantir a resposta de seus seguidores a ofertas específicas. Conseqüentemente, estas assumiam a forma de tentativa e erro, e raramente tinham êxito. Cardoso, no Brasil, foi bem-sucedido ao mostrar reações mínimas aos protestos não-violentos contra ele e esperar que se dispersassem. O exemplo mais impressionante de "negociação" com a rua veio depois que De la Rúa caiu na Argentina, onde os manifestantes conseguiram rejeitar seu primeiro sucessor verdadeiro, Rodríguez Saá. Nos meses subseqüentes, muitas diretrizes econômicas foram "abertamente avaliadas pelos políticos, em termos de seu potencial de provocar um "panelaço"’46.

\footnotetext{
${ }^{44}$ WR-02-01; WR-02-15.

${ }^{45}$ WR-03-44.

${ }^{46}$ WR-02-02, p. 14
} 
À medida que presidentes e povo representam esses cenários, os partidos e o Legislativo estabelecem uma de duas regras. Muitos partidos tradicionais parecem ter concluído que seu apoio aberto aos protestos de rua poderia minar os contestadores. Em 2002, os políticos do Partido Colorado do Paraguai, que tentavam afastar o substituto de Cubas, orquestraram protestos que, segundo se dizia, eram de organizações da sociedade civil, apenas para, no final, as organizações exporem os manifestantes como falsos $^{47}$. Da mesma forma, membros do Partido Peronista da Argentina assumiram abertamente a responsabilidade pelos conflitos envolvendo saques de comida, em nível local, mas as contestações em nível nacional a De la Rúa só eram apoiadas secretamente pela liderança peronista, que se viu também sob ataque das ruas após substituí-lo ${ }^{48}$. Apesar disso, os protestos de rua pela sociedade civil dependiam, muitas vezes crucialmente para terem êxito, da inação legislativa, como era também o caso na Argentina ${ }^{49}$. Da mesma forma, na Bolívia, Sanchez de Lozada renunciou com relutância só depois que seu vice-presidente e, em seguida, os partidos da coalizão governamental indicaram que não poderiam apoiá-lo ${ }^{50}$.

Os manifestantes de rua freqüentemente trabalhavam ombro a ombro com os novos partidos, com os quais tinham fortes laços. Os protótipos mais antigos desse tipo foram as contestações de 1995 e 1996 a Cardoso no Brasil, lideradas pelo Partido dos Trabalhadores (PT) e pelo Partido Democrático Trabalhista (PDT). Ambos os partidos têm ligações com sindicatos, e o PT também tem sólidas relações com movimentos sociais. No entanto, essas mobi-

\footnotetext{
${ }^{47}$ WR-02-29.

${ }^{48}$ Auyero e Moran, s.d., p. 1; Peruzzotti, s.d., p. 1.

${ }^{49}$ Schamis, 2002, p. 85.

${ }^{50}$ WR-03-41. Além disso, os governos brasileiro e argentino orientaram em favor da renúncia, diante da não-governabilidade depois da repressão violenta.
} 
lizações, com sua forte orientação partidária, foram capazes de mobilizar menos de um décimo dos participantes das mobilizações suprapartidárias de 1992, e não tiveram êxito em seu objetivo de derrubar o presidente. Da mesma forma, agora há partidos ou equivalentes de partidos no Equador e na Bolívia, que são ligados a organizações indígenas, sindicais e outras da sociedade civil ${ }^{51}$. Essas têm tido mais sucesso. Apesar da presença de partidos políticos e até de alguns representantes do Congresso, a lógica partidária e eleitoral não é dominante na maioria desses protestos. Nenhuma das contestações ocorreu no último ano de mandato do presidente. Vale ressaltar, também, que apenas três líderes de protestos - Gutiérrez, no Equador, Lula, no Brasil, e Toledo, no Peru - eventualmente se tornaram presidentes, e todos ao se candidatarem em novas eleições.

Os níveis de violência dos protestos e o fato de que as contestações exclusivas de rua raramente tiveram como alvo comportamentos que poderiam exigir um impeachment são motivos potenciais de preocupação acerca desses tipos de contestações e suas implicações para a democracia. Assim é que Roberto Laserna, ao escrever sobre os movimentos de protesto que afastaram Sanchez de Lozada na Bolívia em 2003, critica "um movimento conservador populista, que articula nostalgias comunitárias e estatizantes" e lamenta que a cidadania democrática seja vista como só direitos e nenhuma responsabilidade ${ }^{52}$. Valenzuela também se preocupa com o fato de as convulsões sociais do protesto contra presidentes poderem levar a crises que ameaçam a ordem constitucional como um todo ${ }^{53}$.

A maioria dos autores, inclusive Valenzuela, salienta a maneira pela qual esses movimentos de protesto surgem

\footnotetext{
${ }^{51}$ Yashar, 1999.

${ }^{52}$ Laserna, 2003, pp. 4-14.

${ }^{53}$ Valenzuela, 2004, pp. 5-19. 
das frustrações do que agora são várias décadas de democracia incompleta e problemática ${ }^{54}$. Também ao escrever sobre a Bolívia, mas antes da queda de Sanchez de Lozada, Laurence Whitehead resume uma litania de preocupações subjacentes a muitas interpretações dessa nova rodada de contestações a presidentes.

Por trás de cada movimento estava a convicção de que uma geração de reformas liberalizantes tinha fracassado no sentido de fazer chegar benefícios tangíveis à maioria das pessoas; de que os partidos políticos de todas as colorações se tinham tornado cliques egoístas, que só se preocupam com seus interesses; de que apenas a ação direta em desafio à autoridade pública poderia trazer quaisquer mudanças válidas para a política de governo; de que todos os procedimentos institucionais eram instrumentos para adiar e frustrar as demandas públicas; e de que quem quer que se recusasse a seguir essa lógica perderia para quem agisse primeiro ${ }^{55}$.

Parafraseando Laverna, os manifestantes concluíram que apenas os políticos acham que a democracia implica só direitos e nenhuma responsabilidade. Sob essa ótica, os protestos são processos democráticos, com a sociedade civil buscando ter uma voz nos casos em que fora quase que excluída, ou, como Lucero argumenta - em favor dos movimentos indígenas do Equador -, simplesmente engajando-se no processo histórico do estabelecimento de direitos através da contestação política ${ }^{56}$. Se as observações de Whitehead são literalmente verdadeiras em todos os países da América do Sul nos primeiros anos do século XXI, uma questão que está além do âmbito deste artigo, é fato inegável que a maior parte dos países sul-americanos tem movimentos

\footnotetext{
${ }^{54}$ Crabtree, 2001, Lucero, 2001; Valenzuela, 2004; Wise e Roett, 2003.

${ }_{55}^{55}$ Whitehead, 2001, p. 13.

${ }^{56}$ Lucero, J. A. 2001.
} 
que compartilham dessas convicções e que estão agindo de modo correspondente.

\section{Conclusão: os atores envolvidos e o presidencialismo}

Este artigo identificou o fenômeno da queda presidencial e examinou um conjunto de contestações a presidentes da América do Sul, de 1978 a 2003. De modo empírico, ele concluiu que os presidentes contestados compartilham um conjunto de fatores de risco probabilísticos: políticas neoliberais, implicação pessoal em escândalos e posição minoritária no Congresso. Ao mesmo tempo, a dinâmica das recentes contestações aos presidentes e seus resultados parece estar vinculada ao fenômeno complicado, multivocal e menos estudado do protesto popular de rua. A conclusão apresenta breves observações sobre cada uma das categorias de participantes - presidentes, legisladores e povo -, na medida em que apareceram na recente política sul-americana. Seus padrões de interação exigem nova atenção ao presidencialismo e a suas possíveis diferenças nas diversas regiões do mundo.

Num regime presidencial, os presidentes inevitavelmente estão à parte e acima de outros atores políticos, com seus poderes especiais e fontes especiais de legitimidade $^{57}$. Desde 1978, as dimensões e as formas exatas daqueles poderes estiveram na agenda política dos países da América do Sul quase que constantemente. A enorme quantidade de tempo e de energia gasta nas contestações a presidentes naqueles anos é ainda mais uma demonstração de como eles são importantes. Ao mesmo tempo, as contestações regulares aos presidentes naqueles anos indicam o quanto são vulneráveis à retirada de sua legitimidade especial. O povo, evidentemente, pode e tem retirado os mandatos que deram aos presidentes para que o gover-

\footnotetext{
${ }^{57}$ Valenzuela, 2004.
} 
nassem, e poucos têm sobrevivido a grandes e violentas manifestações contra eles.

O fenômeno da queda presidencial sugere várias observações quanto ao Legislativo e seus relacionamentos, tanto com os presidentes quanto com o público. Em eventos políticos extremos, como o afastamento do cargo, o Poder Legislativo emerge mais forte na prática do que seria de se esperar em função de sua fraqueza relativa em momentos de política mais normal. O Poder Legislativo participou do afastamento de cinco presidentes, embora eles freqüentemente procurem atalhos constitucionais durante esse processo. Em contrapartida, só o presidente peruano Fujimori conseguiu fechar o Legislativo, apesar dos boatos de outros "Fujimorazos", doze vezes em diferentes países da América do Sul. As populações também não se voltaram contra os legisladores da mesma forma que derrubaram presidentes. Houve apenas dois casos de protestos em massa contra Congressos: as mobilizações "que se vayan todos" na Argentina, após a queda de De la Rúa, e uma fúria semelhante nas ruas do Equador em 2000, depois que o golpe sociedade civil/ militar fracassou. Pode haver algumas diferenças na natureza do mandato dado aos presidentes, em contraposição ao do Poder Legislativo, talvez ligadas à sua separação de objetivos $^{58}$. Uma hipótese alternativa é que talvez seja simplesmente complicado demais derrubar um grupo de participantes tão diversos quanto aqueles que participam de um Congresso.

Ao afirmar a força inesperada do Poder Legislativo, este artigo também mostra que os legisladores podem exercer o seu poder contra os presidentes apenas com aliados da sociedade civil. Um dos argumentos básicos deste artigo é que os cientistas políticos precisam dedicar mais atenção às relações Estado/sociedade, a fim de compre-

\footnotetext{
${ }^{58}$ Samuels e Shugart, 2003.
} 
ender os resultados políticos e a qualidade da democracia, em vez de dar tanto destaque às instituições de elite. Parece claro que os políticos e os partidos sul-americanos são cada vez menos capazes de canalizar uma porção significativa de agitação social e de demandas para instituições políticas existentes, uma conclusão que é apoiada por evidências muito diferentes, tanto no que se refere a filiações partidárias quanto no tocante a eleições ${ }^{59}$. Quer sejam a sociedade civil, a sociedade política, ou ambas, as responsáveis por essa ruptura, as representações devem se engajar em nome tanto da qualidade quanto da estabilidade da democracia regional.

Uma pesquisa mais ampla nessa direção poderia enfocar não apenas protestos populares de rua, mas também outros dados relacionados à população como um todo, tais como a opinião pública, estatísticas de desemprego e presença ou ausência permanentes de participantes de rua que podem efetivamente tanto vetar políticas quanto contestar presidentes.

De modo global, este artigo acrescenta outro tipo de evidência para apoiar os argumentos de que, pelo menos na América do Sul, o presidencialismo é um sistema político com deficiências e vulnerabilidades específicas. No entanto, não são necessariamente como as identificadas até hoje. Não apenas as duplas legitimidades democráticas dos presidentes e dos legisladores os levam à competição ${ }^{60}$, como a capacidade não-prevista da população de retirar os mandatos de presidentes significa que o povo continua um participante ativo no desenvolvimento das presidências. Pode ser um apoio crucial a qualquer um dos lados nas disputas em andamento entre o Poder Executivo e o Poder Legislativo, e merece um estudo mais aprofundado como tal. Em

\footnotetext{
${ }^{59}$ Roberts e Wibbels, 1999, pp. 575-590.

${ }^{60}$ Linz e Valenzuela, 1994.
} 
segundo lugar, os $40 \%$ de presidentes sul-americanos que foram contestados pelos legisladores ou por movimentos populares de protesto, e os $23 \%$ que foram forçados a deixar seus cargos prematuramente, confirmam que os mandatos presidenciais não são tão rigorosamente definidos em sua duração quanto sugere a discussão teórica. Essas duas observações apóiam o argumento de que o presidencialismo sul-americano tende ao colapso.

No entanto, a versão de colapso não é a queda para o autoritarismo que a maioria teme. Desajeitadas, violentas, incertas, as contestações aos presidentes sul-americanos após 1978 resultaram em novos governos civis. Schamis credita a sobrevivência da democracia na Argentina a instituições especiais quase-parlamentares ${ }^{61}$, mas todos esses países em que os presidentes caíram produziram resultados semelhantes, com uma variedade de procedimentos. Enquanto os detalhes variam, eles também passaram por um período de "negociações de alto nível", que é típico dos sistemas parlamentares após a realização de uma eleição ou o colapso de um governo, e emergiram com um presidente novo, algum tipo de mandato, e prosseguiram ${ }^{62}$. A expressão parlamentar "moção de desconfiança" é também utilmente evocativa das formas pelas quais o eleitorado pode retirar o mandato que conferiu ao presidente para governá-lo. Dessa forma, a muitas vezes lamentada flexibilidade institucional dos países sul-americanos pode estar produzindo seu próprio tipo híbrido de parlamentarismo e presidencialismo na prática, que tem ajudado a criar a inesperada estabilidade da democracia eleitoral básica na região, mesmo enquanto presidentes caíam individualmente. Esse comportamento híbrido pode também aparecer no processo rotineiro de tomada de decisões ${ }^{63}$.

${ }^{61}$ Schamis, 2002, pp. 90-91.

${ }^{62}$ Schamis, 2002, p. 91.

${ }^{63}$ Lamounier, 2003, pp. 269-291. 
Esses importantes fenômenos de contestações a presidentes e quedas presidenciais não se limitam à América do Sul, como mostram as experiências do presidente Estrada (Filipinas), de Bill Clinton, nos Estados Unidos, e outras. Um próximo e óbvio passo para a pesquisa é catalogar as contestações ao presidencialismo fora da América do Sul e suas causas e resultados. Já que este artigo se limita apenas a experiências sul-americanas, ele não pode tirar conclusões sobre o fenômeno no nível mundial. Certamente, a América do Sul é fora do comum quanto ao número de contestações e à extrema flexibilidade de seus mandatos presidenciais, sobretudo se comparada ao caso clássico do presidencialismo dos Estados Unidos e seus permanentes mandatos rígidos. No entanto, a América do Sul pode ser um ponto de partida melhor para se entender os fenômenos gerais do presidencialismo e das quedas de presidentes. A transição e a consolidação políticas cruzam-se com as instituições do presidencialismo em modos que, provavelmente, tornam suas experiências mais úteis para a compreensão da dinâmica dos muitos novos sistemas presidenciais da África e da Ásia. Se as motivações mais específicas das contestações se mantiverem, e se os protestos de rua são igualmente decisivos em outros lugares, são questões empíricas em aberto, embora valha a pena notar que a contestação sem êxito a Clinton também fracassou na mobilização de apoio das ruas. De qualquer forma, o fenômeno da queda de um presidente merece pesquisa adicional e parece mais importante para o presidencialismo atual do que uma total ruptura de regime.

\section{Kathryn Hochstetler}

é professora do Departamento de Ciência Política da Universidade do Novo México (EUA) 


\section{Referências bibliográficas}

ABENTE-BRUN, D. 1999. "People power in Paraguay". Journal of Democracy, $\mathrm{n}^{\circ} 10$, julho, pp. 93-100.

AMORIM NETO, 0. 2006. "The presidential calculus: Executive policy-making and cabinet formation in the Americas". Comparative Political Studies, $\mathrm{n}^{\mathrm{o}} 39$, agosto.

AUYERO, J.; MORAN, T. P. s.d. The dynamics of collective violence: dissecting food riots in contemporary Argentina. Manuscrito não publicado, p. 1.

BAUMGARTNER, J. C. 2003. "Introduction: comparative presidential impeachment". In: BAUMGARTNER, J. C.; KADA, N. (orgs.). Checking Executive power: presidential impeachment in comparative perspective. Westport, CT: Praeger.

KADA, N. (orgs.). 2003. Checking Executive power: presidential impeachment in comparative perspective. Westport, CT: Praeger.

CAREY, J. M. 2003a. "Presidentialism and representative institutions". In: DOMÍNGUEZ, J. I.; SHIFTER, M. (ed.). Constructing democratic governance in Latin America. $2^{\text {a }}$ ed. Baltimore: The Johns Hopkins University Press, pp. 22-25.

2003b. "Transparency vs. collective action: Fujimori's legacy and Peruvian Congress". Comparative Political Studies, $n^{\circ} 36$, novembro, pp. 983-1.006.

CHEIBUB, J. A. 2002. "Minority governments, deadlock situations, and the survival of presidential democracies". Comparative Political Studies, $\mathrm{n}^{\circ} 35$, abril, pp. 284-312.

COMISIÓN Ciudadana de Seguimiento. 1996. Poder, justicia y indignidad: el juicio al presidente de la República Ernesto Samper Pizano. Bogotá: Comisión Ciudadana de Seguimiento.

CONAGHAN, C. M.; MALLOY, J.; ABUGATTAS, L. A. 1990. "Business and the boys: the politics of neoliberalism in the Central Andes. Latin American Research Review, $\mathrm{n}^{\circ}$ 25, pp. 3-30.

CRABTREE, J. 2001. "The collapse of fujimorismo: authoritarianism and its limits". Bulletin of Latin American Research, n 20, julho, pp. 295.

DUGAS, John C. 2001. "Drugs, lies and audiotape: the samper crisis in Colombia (Review Essay)”. Latin American Research Review, n ${ }^{\circ} 36$, pp. 157174.

FLYNN, Peter. 1993. "Collor, corruption and crisis: time for reflection". Journal of Latin American Studies, $\mathrm{n}^{\circ}$ 25, maio, pp. 351-371.

FRIEDMAN, E. J.; HOCHSTETLER, K. 2002. "Assessing the third transition in Latin American democratization: civil society in Brazil and Argentina". Comparative Politics, $\mathrm{n}^{\circ} 35$, outubro, pp. 21-42. 
GARCÍA CALDERÓN, E. 2001. "High anxiety in the Andes: Peru's decade of living dangerously". Journal of Democracy, $\mathrm{n}^{\circ}$ 12, abril, pp. 59-73.

GEDDES, B. 2003. Paradigms and sand castles: theory building and research design in comparative politics. Ann Arbor: University of Michigan Press.

ISAACS, A. 1991. "Problems of democratic consolidation in Ecuador". Bulletin of Latin American Research, $\mathrm{n}^{\circ}$ 10, pp. 221-238.

KADA, N. 2003. "The role of investigative committees in the presidential impeachment processes in Brazil and Colombia”. Legislative Studies Quarterly, $\mathrm{n}^{\circ}$ 28, fevereiro, pp. 29-54.

KENNEY, C. D. 2004. Fujimori's coup and the breakdown of democracy in Latin America. Notre Dame: University of Notre Dame Press, pp. 264-266.

KING, G.; TOMZ, M.; WITTENBERG, J. 2000. "Making the most of statistical analyses: improving interpretation and presentation". American Journal of Political Science, $\mathrm{n}^{\circ}$ 44, abril, pp. 347-361.

KOOPMANS, R.; RUCHT, D. 1999. "Protest event analysis - Where to now?". Mobilization: An International Journal, $\mathrm{n}^{\circ}$ 4, pp. 123-130.

LAMBERT, P. 2000. "A decade of electoral democracy: continuity, change and crisis in Paraguay”. Bulletin of Latin American Research, $\mathrm{n}^{\circ}$ 19, pp. 392 , julho.

LAMOUNIER, B. 2003. "Brazil: an assessment of the Cardoso administration”. In: DOMÍNGUEZ, J. I.; SHIFTER, M. (orgs.). Constructing democratic governance in Latin America. $2^{\text {a }}$ ed. Baltimore: The Johns Hopkins University Press, pp. 269-291.

LASERNA, R. 2003. "Bolivia: entre populismo y democracia". Nueva Sociedad, $\mathrm{n}^{\circ} 188$, novembro/dezembro, pp. 4-14.

LINZ, J. J. 1994. "Presidential or parliamentary democracy: does it make a difference?”. In: LINZ, J.; VALENZUELA, A. (orgs.). The failure of presidential democracy. Baltimore/London: The Johns Hopkins University Press.

; VALENZUELA, A. (orgs.). 1994. The failure of presidential democracy. Baltimore/London: The Johns Hopkins University Press.

LUCERO, J. A. 2001. "High anxiety in the Andes: crisis and contention in Ecuador". Jornal of Democracy, n ${ }^{\circ}$ 12(2), pp. 59-73.

2006. "Representing 'real indians': the challenges of indigenous authenticity and strategic constructivism in Ecuador and Bolivia". Latin American Research Review, University of Texas, Austin, vol. 41, n 2, junho, pp. 31-56.

MAINWARING, S. 1993. "Presidentialism, multipartism, and democracy: the difficult combination”. Comparative Political Studies, n 26, pp. 198-228.

NOBRE, M. 1992. "Pensando o impeachment". Novos Estudos Cebrap, $\mathrm{n}^{\circ} 34$, novembro, pp. 15-19. 
PÉREZ-LIÑAN, A. 2003a. "Presidential crises and democratic accountability in Latin America, 1990-1999". In: ECKSTEIN, Susan E.; WICKHAM-CROWLEY, Timothy P. (orgs.). What justice? Whose justice? Fighting for fairness in Latin America. Berkeley and Los Angeles: University of California Press.

2003b. "Pugna de poderes y crisis de gobernabilidad: hacia un nuevo presidencialismo?”. Latin American Research Review, n 38 , outubro, pp. 149-164.

PERKINS, W. B. 2003. "The political nature of presidential impeachment in the United States”. In: BAUMGARTNER, J. C.; KADA, N. (orgs.). Checking Executive power: presidential impeachment in comparative perspective. Westport, CT: Praeger.

PERUZZOTTI, E. s.d. Civic engagement in Argentina. From the human rights movement to the Cacerolazos. Manuscrito não publicado, p. 1.

ROBERTS, K. M.; WIBBELS, E. 1999. "Party systems and electoral volatility in Latin America: a test of economic, institutional and structural explanations". American Political Science Review, n ${ }^{\circ}$ 93, setembro, pp. 575-590.

ROMERO, A. 1997. "Rearranging the deck chairs on the Titanic: the agony of democracy in Venezuela". Latin American Research Review, n ${ }^{\circ}$ 32, p. 15.

SAMUELS, D. J.; SHUGART, M. S. 2003. "Presidentialism, elections and representation". Journal of Theoretical Politics, $\mathrm{n}^{\circ}$ 15, janeiro, pp. 33-60.

SARTORI, G. 1994. Comparative constitutional engineering. $2^{\mathrm{a}}$ ed. New York: New York University Press.

SCHAMIS, H. E. 2002. Argentina: crisis and democratic consolidation". Journal of Democracy, $\mathrm{n}^{\circ} 13$, abril, pp. 81-94.

STOKES, S. C. 2001. Mandates and democracy: neoliberalism by surprise in Latin America". Cambridge: Cambridge University Press.

TOMZ, M.; WITTENBERG, J.; KING, G. 2003. Clarify: software for interpreting and presenting statistical results. Versão 2.1. Stanford University: University of Wisconsin, e Harvard University, $\mathrm{n}^{\circ} 5$, janeiro. Disponível em: gking. harvard.edu.

VALENZUELA, A. 2004. "Latin American presidencies interrupted". Journal of Democracy, $\mathrm{n}^{\circ} 15$, outubro, pp. 5-19.

WEEKLY Report. Vários números. Disponível em: www.latinnews.com/lwr/ Lawr2315.asp.

WEYLAND, K. 1993. "The rise and fall of president Collor and its impact on Brazilian democracy". Journal of Interamerican Studies and World Affairs, $\mathrm{n}^{\circ} 35$, pp. 1-37.

2002. "Limitations of rational-choice institutionalism for the study of Latin American politics". Studies in Comparative International Development, $\mathrm{n}^{\circ} 37$, janeiro, pp. 57-85. 
Repensando o presidencialismo: contestações e quedas de presidentes na América do Sul

WHITEHEAD, L. 2001. "High anxiety in the Andes: Bolivia and the viability of democracy". Journal of Democracy, ${ }^{\circ}$ 12, abril, pp. 6-16.

WISE, C.; ROETT, R. (orgs.); PAZ, G. (assist.). 2003. Post-stabilization politics in Latin America: competition, transition, collapse. Washington, D.C.: Brookings Institution.

YASHAR, D. J. 1999. "Democracy. Indigenous movements and the post liberal challenge in Latin America”. World Politics, $n^{\circ}$ 52, outubro, pp. 76-106. 


\section{REPENSANDO 0 PRESIDENCIALISIMO: CONTESTAÇÕES E QUEDAS DE PRESIDENTES NA AMÉRICA DO SUL}

\section{KATHRYN HOCHSTETLER}

A partir de 1978, 40\% dos presidentes eleitos na América do Sul têm sido contestados por civis, que tentaram fazêlos deixar o cargo antes do tempo. Por meio de impeachments e de renúncias, caíram $23 \%$ - que foram substituídos por civis. Após um exame do conjunto completo de presidências, verifica-se que os presidentes contestados tendiam mais a seguir políticas neoliberais, a estarem pessoalmente implicados em escândalos e a não terem maioria no Congresso, do que seus congêneres não-contestados. Entre os presidentes contestados, a presença ou a ausência de grandes manifestações populares nas ruas, exigindo sua deposição, é, então, crucial para determinar seus destinos. Esses acontecimentos frustram várias hipóteses essenciais relativas às práticas dos regimes presidenciais: que os mandatos presidenciais são rigorosamente fixados, que a população não pode retirar nem garantir seus mandatos e que as conseqüências do conflito político no presidencialismo são o colapso da democracia.

Palavras-chave: Presidencialismo; Contestações de rua; Mandatos eleitorais; América do Sul.

\section{RETHINKING PRESIDENTIALISM: CHALLENGES AND FALLS OF PRESIDENTS IN SOUTH AMERICA}

Since 1978, forty percent of elected presidents in South America have been challenged by civilian actors trying to force them to leave office early. Through impeachment and resignations, twenty three percent have fallen - and been replaced by civilians. It seems that challenged presidents were more likely to pursue neo-liberal policies, be personally implicated in scandal, and lack a congressional 
majority than their unchallenged counterparts. Among challenged presidents, the presence or absence of large street protests demanding they be removed from office is then crucial in determining their fates. These developments confound several core assumptions about presidential regimes: that presidential terms are firmly fixed, that populations cannot withdraw as well as grant presidential mandates, and that the consequences of political conflict in presidentialism are democratic breakdown.

Keywords: Presidentialism; Street challenges; Electoral mandates; South America.

\section{VAMOS AO BAILE: GINGAS DA COMUNICAÇÃO E DA PARTICIPAÇÃO NO ZAPATISMO}

\section{GUILHERME GITAHY DE FIGUEIREDO}

Entre 1983, ano em que foi criado como órgão das Forças de Libertação Nacional, até 1996, ano do I Encontro Intercontinental pela Humanidade e Contra o Neoliberalismo realizado em plena selva mexicana, o Exército Zapatista de Libertação Nacional (EZLN) viveu uma lenta e decisiva transformação: de guerrilha clássica a movimento pacífico que constrói "um mundo onde caibam muitos mundos", por meio da invenção de mecanismos de participação e comunicação. Este texto analisa essas novas maneiras de fazer política que têm sido cultivadas nas relações entre o EZLN e a por ele denominada "sociedade civil", que são inúmeros grupos a ele associados por laços de comunicação e solidariedade.

Palavras-chave: Zapatismo; Sociedade civil; México.

\section{LET'S GO TO THE BALL: SWINGS OF COMMUNICATION AND PARTICIPATION IN ZAPATISM}

Since 1983, year when it was created as an agency of the National 